\title{
The impact of inquiry-based, group-work approaches to instruction on both students and their peer leaders
}

\author{
George Bodner ${ }^{1}$ and Ridvan Elmas ${ }^{2}$ \\ ${ }^{1}$ Department of Chemistry, Purdue University, West Lafayette, IN, USA \\ ${ }^{2}$ Department of Science Education, Afyon Kocatepe University, Afyonkarahisar, Turkey \\ For correspondence: relmas@aku.edu.tr
}

\begin{abstract}
:
Discipline-based educational research (DBER) has shown that three instructional techniques - Supplemental Instruction (SI), Process-Oriented Guided Inquiry Learning (POGIL), and Peer-Led Team Learning (PLTL) - can be effective ways of improving student performance in chemistry courses at the K-12 or college/university levels. The goal of this paper is to use an analysis of the literature to compare and contrast these instructional techniques and, when possible, to determine "best practices" for their implementation. Particular attention will be paid to four themes related to the impact of PLTL on students, impact on peer-team-leaders, how to motivate peer leaders, and impact of peer leaders on the instructors who implement PLTL in their classroom.
\end{abstract}

Keywords: Peers, Peer Tutoring, Peer Leaders, Peer-Led Team Learning (PLTL), Process Oriented Guided Inquiry Learning (POGIL), Supplemental Instruction (SI)

\section{Introduction}

Both educators and educational researchers throughout the world are involved in a continuous process of searching for better approaches to creating learning environments best suited to the needs of students who enroll in their courses (Light, 1992; Groccia\& Miller, 1996; Apugliese\& Lewis, 2017). Some of these individuals focus their attention on the search for "best practices" in determining the content of the course. Others search for "best practices" in the processes of teaching and learning, which often involve promoting student-centered instructional techniques that involve an inquiry-based approach in which students become active learners (AAAS, 1994).

Inquiry-based instruction often includes some form of support from either the students' peers, teaching assistants, or instructors (Eberlein, et al., 2008). Research on the effect of inquiry-based learning has shown that the use of peer-, TA-, or instructor-supported inquiry-based learning environments leads to improvement in both what is learned and students' attitudes toward the content of these courses (HmeloSilver, Duncan \& Chinn, 2007; Elmas\&Geban, 2016). Furthermore, there is evidence that inquiry-based instruction that provides only minimal peer, TA, or instructor guidanceinevitably leads to less effective teaching and learning (Kirschner, Sweller\& Clark, 2006; Lazonder\&Harmsen, 2016). Even at the level of graduate student courses, guidance from a "more knowledgeable other" has been shown to have a significant positive effect (Bhattacharyya \& Bodner, 2014). 
A theoretical model that explains why support from either one's peers or an instructor can have a beneficial effect on student performance can be found in the concept of the zone of proximal development (Vygotsky, 1980; 2012), which provided the basis for the commonly invoked idea of "scaffolding." The zone of proximal development (ZPD) was defined as:

"... the distance between the actual developmental level as determined by independent problem solving and the level of potential development as determined through problem-solving under adult guidance, or in collaboration with more capable peers" (Vygotsky, 1980, p. 86).

The term proximal in Vygotsky's model is used in the sense of a skill that the learner is close to developing. In common practice, the ZPD is often considered to be the difference between what learners can do without help and what they can achieve with help and guidance from a "more capable peer" or an adult who is a "more knowledgeable other." There is a reason to believe, however, that "more competent peers" might be the most appropriate source of additional support (Tudge, 1992; Treisman, 1992).

Peer tutoring is a practice-driven idea that has been in use at many colleges and universities for three or more decades to help students achieve better results in chemistry courses (Bruffee, 1984; Wagner, 1982; Treisman, 1992; Ding \&Harskamp, 2011). Peer tutors have been described by various names, such as peer learning assistants (Groccia\& Miller, 1996), peer instructors (Gerena\&Keiler, 2012), and peer leaders (Hockings, DeAngelis \& Frey, 2008). The use of the term peer in this context can be misleading. They are not peers in the sense of other students in a cooperative learning environment (Bodner \& Metz, 2014). They are more capable peers who took the course previously.

Interactions with more capable peers provide the basis for the mutual exchange of experiences and explanations of concepts in which the less-experienced peer can fill in gaps and thereby develop new skills for dealing with new types of problems they encounter in a course. One of the significant advantages of peer interactions is their tendency to involve the use of similar language, which may not happen when students interact with teaching assistants or instructors.

A meta-analysis of the academic benefits of peer tutoring has shown that it provides a social context for interaction among peers that can have a powerful effect on achievement and motivation (BowmanPerrott, et al., 2013). However, it is within this social context that the most frequently encountered critique of peer tutoring arises: "Isn't it the blind leading the blind?" (Bruffee, 1984). To achieve the potential benefits of peer tutoring, it is essential to train the peer tutors to minimize this problem and students should be willing to take advantage of the social interaction and impact peer tutoring can provide (Chan \& Bauer, 2015). Fortunately, a handbook for PLTL team leaders is available (Roth, Goldstein \& Marcus, 2001) and training manuals for SI team leaders developed for use at wide variety universities can be found on the internet.

Two of the three active learning environments described in this paper are based upon peer tutoring (SI and PLTL), whereas the third (POGIL) is instructor driven. Each of these approaches has much to offer, and each has particular processes, procedures, and applicability (Eberlein, et al., 2008).

\section{Supplemental Instruction}

Supplemental Instruction (SI) was created at the University of Missouri - Kansas City in 1973 to address the problem of a high attrition rate and was first applied to a variety of courses in the professional schools of dentistry, pharmacy, and medicine (Blanc, DeBuhr \& Martin, 1983; Burmeister, 1996). The goal of SI is to provide the support that helps students improve their academic achievement by bringing together 
groups of students enrolled in high-risk courses to work with upper-level students or instructional staff, usually on a weekly basis (Arendale, 1994; Parkinson, 2009). A variety of names have been used for similar programs in other countries, including peer-assisted study sessions (PASS) in Australia (Miller, Oldfield \& Bulmer, 2012) and peer-assisted learning support (PALS) in the UK (Parkinson, 2009). Supplemental instruction can differ significantly from one institution to another, or from one course to another at the same institution (Dawson, et al., 2014).

SI usually occurs in the absence of any input from the instructor teaching the course. A problematic issue with SI is the absence of peer tutor training at many institutions, or training that does not address differences between the courses for which SI is provided. In spite of these limitations, SI can significantly improve the performance of students enrolled in high-risk STEM courses (Malm, Bryngfors\&Mörner, 2012; Parkinson, 2009; Peterfreund, et al., 2008; Congos \& Schoeps, 1993).

At Purdue University, supplemental instruction is offered in first-year courses in Aeronautics and Astronautics, Agricultural Economics, Biology, Chemistry, Computer Science, Economics, Management, Mathematics, Mechanical Engineering, and Physics. The SI program is run by the "Student Success Programs" office, not by the department teaching the course. The SI program is described as developing "academic support communities of higher-level thinkers and self-empowered learners within challenging courses. This self-selecting, peer-led program seeks to promote active, collaborative learning involving critical thinking and transferable study skills." The SI website emphasizes the importance of attending SI sessions early in the semester and as often as the student can. It emphasizes that SI is neither a "quick fix" nor "a place to go for last minute help before an exam." It also notes that SI maximizes students' study time because " 1 hour of productive group study is equal to 2 hours of solo studying." When asked about the effect of participating in the SI program, $89 \%$ of the students said they felt their grade would have been lower if they had not participated in the SI program; $93 \%$ reported that their understanding of the course and their confidence in their knowledge improved; and, on average, $95 \%$ of the students who attended eight or more weekly SI sessions received a grade of $C$ or better in the course.

\section{Process-Oriented Guided Inquiry Learning (POGIL)}

Process Oriented Guided Inquiry Learning (POGIL) is a student-oriented, inquiry-based approach that allows students to engage in well-crafted activities in small groups with the guidance of the instructor (Moog \& Spencer, 2008). Unlike Supplemental Instruction, which is offered by students who are not associated with the course, POGIL is an instructor-supported approach. Whereas Supplemental Instruction occurs outside the lecture or lab classroom, POGIL is used during normal class hours by students working in groups, while the instructor circulates among groups, intervening only when necessary (Eberlein, et al.,2008). The development of POGIL was based on the constructivist theory of knowledge (Bodner, 1986) and the concept of the "learning cycle" (Abraham \& Renner, 1986).

Although POGIL is often associated with introductory college-level chemistry courses, workbooks have also been developed for use in a variety of upper-level courses, including organic (Straumanis \& Simons, 2008; Hein, 2012) and physical chemistry (Hunnicutt, Grushow \& Whitnell, 2014). POGIL has also been used successfully in high-school chemistry courses. Furthermore, POGIL has successfully been extended for use in "biology, physics, mathematics, computer science, engineering, environmental science, education, and in high school settings (predominantly in chemistry and biology)" (Eberlein, et al., 2008)

The key to success with the POGIL approach is the existence of well-crafted activities based on a threephase learning cycle and mastering process skills (Moog, et al., 2009). The learning cycle starts with an 
exploration phase, progresses to a concept invention phase in which connections and patterns in the topic are discovered, and concludes with an application phase in which the new concepts are transferred to contexts with which the students are already familiar.POGIL activities are designed to be completed in one class period and are adapted for use from published workbooks and websites as well as instructor-developed problem sets. The ideal group size for POGIL is assumed to be 3-5 students. Although the ideal class has less than 30 students, techniques have been developed for use in large classes (Ruder \& Hunnicutt, 2008: Yezierski,et al., 2008).

The use of POGIL activities has been shown to decrease therate at which students receive $\mathrm{D}$ or $\mathrm{F}$ grades or withdraw from the course; increase the proportion of $\mathrm{ABC}$ grades; increase the tendency for students to enroll in higher-level chemistry courses; and achieve these results with no reduction in standardized test scores (Eberlein, et al., 2008).

POGIL activities are associated with seven process skills from both the cognitive and affective domains: (1) oral \& written communication, (2) teamwork, (3) problem-solving, (4) critical thinking, (5) management, (6) information processing, and (7) assessment. Further details can be found on the POGIL website (POGIL, 2018).

Individual students in a POGIL team play different roles from oneactivity to the next, including the roles of manager, strategy analyst, recorder/presenter, and so on. Some instructors, therefore, prefer to call the groups "learning teams" (Hanson, 2006). Examples of tasksthat pose critical-thinking questions for use with POGIL-based instruction can be found on the POGIL website (POGIL, 2019). With the guidance of the instructor, these questions can help POGIL teams develop a broader perspective of chemistry (Minderhout \& Loertsher, 2008). As might be expected, the use of POGIL-based instruction has been shown to give rise to a significant improvement in academic achievement (Hein, 2012; Conway, 2014; Gilbert, 2015). It has also been shown to support the development of higher-order process skills, such as critical thinking, teamwork, and self-assessment (Straumanis \& Simons, 2008).

A typical POGIL activity that builds an understanding of the components of an atom has been described (Moog \& Spencer, 2008) as follows:

"The activity begins with a series of diagrams providing examples of a number of atoms and ions, with the corresponding element identified along with the number and location of the protons, neutrons, and electrons in each. Through a series of guiding questions, the students are led to recognize that all of the atoms with the same number of protons are identified as the same element. They also are asked to determine the significance of the number 6 with the number on the periodic table that identifies carbon, and areable to conclude that they are the same. Only at this point, as this concept is developed, is the term "atomic number" used to describe the number of protons in one atom of a given element. Thus, an "exploration" of the information presented in the diagrams allows each student to develop the concept that the number of protons determines the identity of an element; the term "atomic number" is introduced following this construction. The "application" of this concept entails using the periodic table to identify the number of protons in other elements" (p. 4).

Typical POGIL activities for use in high-school chemistry courses have also been developed (Trout, 2012).

Whereas both supplemental instruction and POGIL have been shown to improve academic achievement, there are significant differences between these approaches. As its name suggests, SI is a supplemental form of teaching that occurs outside of regular course hours, whereas POGIL is an approach to instruction that is used during regular class hours. SI often occurs in the absence of any explicit link 
between the SI tutors and the instructor of the course, whereas POGIL is done by the instructor. POGIL utilizes carefully constructed, inquiry-based, learning-cycle activities developed by or chosen for use by the instructor, whereas the structure of the exercises used during supplemental instruction is based on what is deemed appropriate by the SI tutors. POGIL assumes that a specified number of students will work together as a team, whereas SI is delivered to groups of students working as individuals. The role of individual students working on POGIL activities is often specified, so that the group functions as a team. Peer interaction is, therefore, an essential element of the POGIL classroom, whereas SI is often a teachercentered approach to instruction.

Given the structural differences between supplemental instruction and POGIL, one could ask: Why would one use SI? One answer is simple: It works. For more than thirty years, research has shown that SI has a beneficial effect on student performance (Blanc, DeBuhr \& Martin, 1983; Arendale, 1994). Another answer can be viewed within the context of research done with beginning K-12 science teachers, which noted a difference between what teachers might hope to achieve in their classrooms and the classroom environment that actually exists because of technical, bureaucratic and personal constraints the instructor faces (Brickhouse \& Bodner, 1992). Because of the many demands on their time as well as constraints related to the size of the course being taught, instructors often take advantage of existing SI programs at their institution.

\section{Peer-Led Team Learning (PLTL)}

In a discussion of the development of context-based chemistry courses, we noted that similar ideas can arise independently, and more or less simultaneously, in different geographic areas (Bodner, 2015). The same thing seems to have happened among chemists searching for a better way to teach their courses. At roughly the same time as the initial work was done that lead to the creation of the POGIL format, another approach to inquiry-based instruction was created that was initially known as "workshop chemistry" (Gosser, et al., 1996; Gosser \& Roth, 1998), but eventually became known as Peer-Led Team Learning (PLTL).

PLTL is a group-based, social learning approach developed in response to the call for active learning (Cracolice\& Deming, 2001). Like POGIL, the primary goal of PLTL was to improve student achievement and students' interest in chemistry. The PLTL approach is based on a social model, involving students working in groups, that uses an active learning environment to develop students' problem-solving skills, as described on thePLTL website (PLTL, 2019).

The following are examples of PLTL questions for use in general chemistry courses as described by Gosser, Strozak and Cracolice (2006).

1. Naturally occurring boron, atomic number 5, is a mixture of two isotopes: boron-10 and boron-11. Work in pairs to sketch representations of each of these atoms, specifically illustrating the difference between the isotopes. When each pair is finished, compare sketches and discuss and resolve any differences.

2. Boron is present in small amounts in the earth. It is a necessary nutrient for plants, although it is toxic to human in large amounts. The boron-10 isotope has a mass of $10.0129 \mathrm{amu}$ and boron-11 has a mass of $11.00931 \mathrm{amu}$. The atomic mass of a natural sample of boron containing both isotopes of boron is $10.811 \mathrm{amu}$.

a. Without using a calculator, choose the best estimate among the following for the percentage abundance of the two boron isotopes:

(I) $40 \%{ }^{10} \mathrm{~B}$ and $60 \%{ }^{11} \mathrm{~B}$ 
(ii) $80 \%{ }^{10} \mathrm{~B}$ and $20 \%{ }^{11} \mathrm{~B}$

(iii) $20 \%{ }^{10} \mathrm{~B}$ and $80 \%{ }^{11} \mathrm{~B}$

(iv) $60 \%{ }^{10} \mathrm{~B}$ and $40 \%{ }^{11} \mathrm{~B}$

b. Calculate the actual percentage abundance of the boron isotopes. How does your calculated value compare with your estimate from part (a)?

3. A soil sample is found to contain $9.00 \times 10=6 \mathrm{~g}$ of boron. Express this mass in amu.

4. Nitrogen is $99.63 \%{ }^{14} \mathrm{~N}$ at $14.00307 \mathrm{amu}$ and $0.37 \%{ }^{15} \mathrm{~N}$ at $15.00011 \mathrm{amu}$. Determine the atomic mass of nitrogen. How does your calculated value compare with the value given in the periodic table?

In the early stage of development, when the technique was still called "workshop chemistry," the students in a lecture section were divided into groups of 6-8 students. Each group worked with an undergraduate group leader, and all of the groups met at the same time in a single, large lecture hall in which a faculty member was present to oversee the whole class (Woodward, Weiner \& Gosser, 1993). As PLTL evolved, the key element that was retained was the presence of a "more knowledgeable other," the undergraduate group leader, who was someone who had taken the course previously (Hockings, DeAngelis \& Frey, 2008).

In many ways, POGIL and PLTL were based on similar assumptions about the importance of active learning with a strong social component created by having groups of students work together in teams. Furthermore, both approaches assumed that progress toward improved conceptual understanding and/or problem-solving performance not only could, but should, be facilitated by a "more knowledgeable other" who played a role consistent with Vygotsky's concept of a "zone of proximal development." Both projects independently recognized that a significant component of the success of these approaches to instruction was the creation of well-crafted activities upon which the groups of students would work. Both projects, therefore, developed workbooks that could be used by instructors to adopt and then adapt appropriate activities for use with particular courses (see, for example, Kampmeier, et al., 2006).

The primary philosophical difference between PLTL and POGIL is the identity of the individual who provides the "scaffolding" upon which the work of the group is built (Eberlein, et al., 2008). In POGIL, the group work is facilitated by the course instructor; in PLTL, it is an undergraduate "peer." As a result, POGIL occurs during the regular course session, whereas, in PLTLit occurs outside of the class hours. Another consequence of the difference in the identity of the individual who facilitates group work is the need to train peer-leaders ineffective ways of working with the students they will lead. Dissemination of the PLTL approach, therefore, required the development of books that describe how team leaders can be trained (Gosser, at al., 2001).

The underlying assumptions upon which the implementation of PLTL is built contain three essential elements. The students in a particular group are expected to work together as a team. The "scaffolding" that leads to improved student performance is the result of having each group work with an undergraduate who has taken the course previously and can therefore be assumed to be "a more knowledgeable other." And, the activities used during PLTL sessions should be well-crafted, inquirybased tasks. Regardless of whether they are conceptual/qualitative or numeric/quantitative, the tasks used in PLTL instruction should involve critical thinking.

The number of students per group will depend on the resources available, but PLTL should be done with groups of no more than eight or at most ten students (Hockings, De Angelis \& Frey, 2008). Peer team leaders should be recruited from students who did well when they took the course; usually in the prior 
year. Peer leaders should be trained to serve as both a role model and a facilitator of group work (Quitadamo, Brahler \& Crouch, 2009). Except for the peer team leaders who work with a course the first time PLTL is used, the training of peer leaders is simplified by the fact that they will have been exposed to the PLTL format when they took the course. Peer leaders are usually paid on an hourly basis for participating in the PLTL program (Woodward, Weiner \&Gosser, 1993; Stewart, Amar \& Bruce, 2007), although students sometimes are rewarded with course credits that appear on their transcript (Wilson \& Varma-Nelson, 2016), depending on the culture of the educational institution. The money needed to hire peer team leaders often comes from savings in the number of teaching assistants assigned to the course. PLTL can be particularly attractive, however, at institutions that do not have graduate students who can serve as TA's or at institutions where the need for TA's is larger than the number of graduate students available. At the K-12 level, the team leaders are more likely to be rewarded with course credits and in letters of recommendation when these students apply for admission to a college or a university.

Peer leaders are often involved in the development of new activities that will be used with the next generation of students. Peer leaders are expected to be supportive and friendly. Although they play an important role as both team leaders and facilitators of group work, peer leaders are not subject-matter experts like instructors or teaching assistants (Roth, Goldstein \& Marcus, 2001). They have the advantage, however, of having recently gone through the course themselves and are therefore more familiar with topics or concepts with which students often struggle than TA's or the instructor. Furthermore, their role is not to be a subject-matter expert, but to guide the group on how to approach a problem; provide more powerful strategies for working on a problem; and improve students' self-confidence. Pazos, Micari, and Light (2010) developed an observation protocol to assess PLTL that is based on the two constructs of problem-solving approach and group interaction style.

At all times, the PLTL team leader's goal should be facilitating the problem-solving process, helping the group solve problems collaboratively, with active participation by every member of the group(Roth, Goldstein \& Marcus, 2001). At the beginning of the course, students are likely to expect more from the team leader, but the PLTL sessions should soon look like groups working collaboratively on a task (Micari, et al., 2010). The role of PLTL team leaders differs significantly from the traditional role played by graduate teaching assistants. TA's have historically concentrated on showing students how to work problems; PLTL team leaders work to develop an environment where a group of students works collaboratively to discover the solution to a task.

\section{Common characteristics of POGIL and PLTL}

Regardless of whether the instructor uses POGIL with groups of students in class or PLTL with groups meeting outside of class, there is an essential characteristic of these inquiry-based approaches to instruction. In each case, there is someone in the room who can recognize when the group of students achieves consensus around the wrong answer.Regardless of whether it is the instructor or a team leader, the individual facilitating the group work can provide hints that the group might be pursuing the wrong path to the answer. Consider an example from one of the authors' (GMB) experience.

The activity started with a 4-L beaker filled about two-thirds with water. When a can of a soft drink (Coke, Pepsi, etc.) is added to the beaker, it sinks to the bottom. When a can of a diet soft drink (Diet Coke, Diet Pepsi, etc.) is added to the water, it floats. The goal of the activity is to show the difference in the overall average density of the two cans because artificial sweeteners used in diet soft drinks are hundreds of times sweeter than sugar. (Aspartame, for example, is 180 timessweeter than sucrose, so much less is added to the soft drink.) One evening, the group 
of non-STEM majors observing the activity came to a consensus among themselves that the diet soda floated because "they took the calories out." The group was eventually led through the process of, first, recognizing that this answer was not correct and, then, toward identifying the difference between the sweeteners used in the two products.

There is abundant evidence that SI, POGIL, and PLTL can have a significant positive effect on students' performance in college-level chemistry courses. But it is important to recognize the differences. SI is a practical tool developed more or less independently at hundreds of institutions as a way to help students struggling with their first college-level course in a wide variety of disciplines.

SI does not build upon any specific theory of learning, and there is no theory guiding how to implement it. The SI instructors often solve problems for students, rather than with students. As a way of thinking about SI, imagine trying to help kids learn how to play soccer. There is no doubt that many hours of watching soccer matches being played by professionals can help beginners understand the game and gain insights into the skills they need to develop. However, watching an expert perform can only get a beginner just so far. To develop expertise, they need to practice playing the game themselves.

Unlike SI, both PLTL and POGIL have a strong theoretical foundation. Both approaches were built on the constructivist theory of knowledge, which assumes that knowledge is constructed in the mind of the learner (Bodner, 1986). The development of POGIL was also influenced by research on the learning cycle, which was itself based on the work of Piaget (Abraham \& Renner, 1986). The development of PLTL was influenced, instead, by Vygotsky's concept of the zone of proximal development (Eberlein,et al., 2008).

The individuals who facilitate the use of POGIL activities are the instructors, who implement this technique in regularly scheduled class sessions, moving from group to group while monitoring their progress. PLTL relies on students who have completed the course previously. Because of the significant overlap in the philosophy of the role of the instructor/team-leader in POGIL and PLTL, it is not surprising that hybrid implementations of these techniques have been described (Lewis \& Lewis, 2005; 2008; Hu, et al., 2014; Wilson \& Varma-Nelson, 2016; 2018).

Wilson and Varma-Nelson (2016) recently published a review of research reported in 67 studies of PLTL across a variety of both STEM disciplines and different institutions. They reported five general themes related to measures of student success: students' perceptions of peer-led team learning; the development of reasoning and critical thinking skills; the effect of participation in PLTL on the peer leaders; and variations in the structure of how peer-led team learning is done. They also outlined areas for further research and the implications of research done so far for classroom practice in STEM disciplines (Wilson \& Varma-Nelson, 2016).

\section{Theoretical frameworks}

As noted previously, both PLTL and POGIL were built on a constructivist framework influenced by the work of Piaget. But, because the unit of analysis in either approach is a group of students working with a team leader or instructor, the development of both PLTL and POGIL was strongly influenced by social constructivist ideas (Steffe \& Gale, 1995). The authors believe there is no conflict between the theoretical frameworks of constructivism and social constructivism. The constructivist theory focuses on the idea that knowledge is constructed in the mind of the learner; the social constructivist perspective accounts for the social interactions that might influence that process (Fawcett \& Garton, 2005). There should be no doubt that learning not only can but does occur on the basis of individuals' interactions with objects in 
their environment. But it can also result from social interactions with one's peers or with what we have called a "more knowledgeable other" (Bhattacharyya \& Bodner, 2014) as a result of verbal/linguistic interactions (Teasley, 1995; Webb \&Farivar, 1999). As might be expected, high-quality verbal interaction has been shown to contribute to higher-level conceptual understanding (King, Staffieri \& Adelgais, 1998).

Both PLTL and POGIL take advantage of the idea of the "more knowledgeable other." In one of these approaches, the "more knowledgeable other" is the instructor, whereas in the other it is a peer who completed the course previously. The instructor has the advantage of bringing more experiential knowledge to interaction. But peer leaders can be more suitable partners because their knowledge base and skills are closer to those of the students encountering the material for the first time. Peer leaders are also more likely to remember situations where they struggled with the course, themselves. It is not surprising that a variety of studies of peer collaboration have shown that teamwork facilitated by a more competent peer has been shown to be useful (Tudge, 1992).

Peer leaders play an essential role in both PLTL and Supplemental Instruction. PLTL has the advantage that the activities upon which groups of students work were created by the instructor and they were designed deliberately for use in this environment. The team leaders, therefore, begin the process of facilitating the team's work by knowing a "correct" answer to the activity. This alleviates the concern that peer leaders might lead students to an erroneous conclusion.

Impactof peerleaders, and impacton peer leaders and instructors

Impact of Peer Leaders

Both SI and PLTL recruit team leaders from among the population of students who had taken the course previously. There is a significant difference, however, in the way team leaders are trained. Whereas the group of team leaders involved in SI at a given institution might come from a wide variety of disciplines, PLTL team leaders came from a limited number of chemistry courses taken by first- or second-year students. Furthermore, the PLTL team leaders were given activities for use with their teams that were carefully constructed for use in the PLTL format. The team leaders can, therefore, be prepared for the task of orchestrating group work on tasks developed bythe course instructor (Gosser, Strozak\&Cracolice, 2006). Peer leaders can alsobe trained to create an environment in which every member of the group has an equal opportunity to present their views; where individual points of view are respected during the problem-solving process; and constructive comments are used by the group to foster the development of an understanding of concepts needed to construct a solution. It is not surprising that studies have shown that students involved in PLTL groups are more responsible and respectful of other people's ideas (Gosser, et al., 2001).

Peer leaders support the expansion of the content knowledge of the students in the group based on their collective work toward finding answers (Drane, Micari\& Light, 2014; Wilson \& Varma-Nelson, 2016). While doing this, peer leaders are expected to clarify the purpose and goals of the PLTL session, support the full participation of all group members, create commitment and self-awareness, empower problemsolving skills, and build better relationships among group members (Gosser, et al., 2001). The enhanced socialization and communication among students in a PLTL group help students get better grades on course exams. The joy of working as a supportive team with the help of peer leaders can also boost students' interest in science, as well (Wilson \& Varma-Nelson, 2016).

Traditionally, many of the students who are required to take a chemistry course to fulfill a requirement in their major bring a negative attitude to the course. They often view the course as nothing more than an 
exercise in solving jargon-rich mathematical problems that have no connection to their view of their career after graduation. They often think about our courses as requiring them to learn too much, too rapidly, to be successful. Working with a peer leader who was successful in the course can have a positive effect on their attitude toward the course. The peer leader helps them recognize that the workload is "doable" if the students are willing to devote the time and energy needed to be successful by themselves.

The peer leaders can function as role model who can affect students' decisions to enroll other science courses (Micari \& Light, 2009). The group work that is at the heart of the PLTL approach can also help students develop their interpersonal skills. They can help them learn more about working in a group toward a common goal, which can play an essential role in their future careers. Peer leaders also have a chance to connect with students one-on-one, which can play a vital role in helping socially or emotionally disadvantaged students, low-income students, or students from underrepresented minorities (BowmanPerrott, et al., 2013; Drane, Micari \& Light, 2014; Smith, et al., 2014).

\section{Impact on Peer Leaders}

The primary goal of inquiry-based instruction is to improve student learning, understanding, retention of information, and so on. Conversations with instructors who have adopted approaches such as POGIL, which are instructor-driven, have indicated that this approach to inquiry-based instruction had beneficial effects on instructors with as many as 20 or more years of teaching experience, who were tired with using the same traditional approach to teaching their courses, year after year. As just one of many examples, consider what happened to one of the authors (GMB) when he returned to the chemistry department in which he had obtained his B.S. One of the faculty who had taught him physical chemistry more than 35 years earlier, reached for a book on his shelf because he was so excited about the volume that described POGIL activities for use in physical chemistry, and wanted to know if he was "familiar with it."

The primary goal of PLTL is the same; to improve student learning, understanding, retention of information, and so on. However, the intrinsic structure of the PLTL experience has a significant, positive effect on the team leaders, as well (Gafney \& Varma-Nelson, 2007).While considering the potential impact of having served as a team leader, it is important to recognize one of the critical features of the PLTL environment: The program assumes that the team leaders will be trained before they take on the responsibility of leading their team or group (Gosser, et al., 2001). There is also the beneficial effect of going through the content material for the second time. But, consider something so many instructors have discovered in their first years in the classroom: No-one in the classroom learns more than the individual teaching a course for the first time. The experience of being a PLTL peer leader can therefore have a positive effect because of the thought process associated with listening to members of their group and thinking about how they would respond if they had to provide guidance if the group is on the wrong track. Serving as a team leader can also have a beneficial effect on the team leader's development of communication skills that are necessary for so many (Gafney \& Varma-Nelson, 2007; Wilson \& VarmaNelson, 2016).

PLTL team leaders have the opportunity to develop useful leadership skills (Roth, Goldstein \& Marcus, 2001). They also get to discuss with experienced faculty associated with the course ways of providing feedback and overcoming problems they encounter working with their team (Gosser, et al., 2001). This process can enhance peer leaders' self-confidence, self-learning, decision-making skills, and intrapersonnel skills (Reyes-Hernandez, et al., 2015; Gafney \& Varma-Nelson, 2007).

It is not surprising that PLTL team leaders often improve their teaching skills by thinking about how to facilitate the work of the novice students within their group or team (Roth, Goldstein \& Marcus, 2001). 
Depending on the course to which they are assigned, and the faculty with whom they work, PLTL team leaders get exposed to ideas from educational theory and pedagogical content knowledge (PCK) that has been developed by competent teachers in their content domain (Shulman, 1986).

PLTL team leaders are likely to develop better problem-solving skills and study habits as a result of their experience (Wilson \& Varma-Nelson, 2016). They are also more likely to become "reflective practitioners" (Schön, 1983), pausing periodically to think about the work they have done and how it might be improved in the future. They are therefore more aware of their approach to learning than other students. While developing social skills and orchestrating the work of their team, they become better at handling the fragile line between offering suggestions without embarrassing or offending members of their team. One of the distinct advantages of inquiry-based approaches such as PLTL is the team leader's ability to extract experiences from the PLTL sessions that will be useful in their future careers (Gosser, et al., 2001) when managing people is a critical skill.

\section{How to Motivate Peer Leaders}

Although students who volunteer to be team leaders are intrinsically motivated, some form of extrinsic motivation may be useful during the semester, to keep them on track. The type of extrinsic motivation used depends on the educational culture of the institution where PLTL is implemented, but the most commonly used strategies are some form of financial compensation, course credit, and the opportunity to request a letter of recommendation when they apply for jobs or admission to graduate/professional schools (Wilson \& Varma-Nelson, 2016). Some form of evaluation of team leaders can also be used as an extrinsic motivation factor (Hockings, DeAngelis \& Frey, 2008). Although extrinsic motivators can be useful, many peer leaders find the PLTL experience so satisfying that intrinsic motivation is all that is needed (Gosser, et al., 2001).

The Impact of Peer Leaders on the Instructors in PLTL

Conversations with instructors who have implemented either PLTL or POGIL suggest the existence of a common belief that the choice of appropriate activities is an important factor in the magnitude of the positive effect observed when these instructional environments are implemented. Another factor that could influence the magnitude of the effect of these approaches to teaching chemistry is the time and effort devoted to the training of team leaders. This is likely to be particularly true during the first year one of these approaches is used because the first group of team leaders will not have experienced this approach when they took the course.

The intrinsic motivation for instructors who implement PLTL in their course has to come from the extensive evidence that this approach leads to improved teaching and learning. It has to overcome, however, the financial burden of locating funds to pay the team leaders. At many institutions, this is not difficult because PLTL team leaders are significantly cheaper than teaching assistants who are assigned to these courses. And very much less expensive than the cost of providing instructors or faculty to lead groups of students.

One of the key benefits to the instructor of implementing PLTL is feedback from the team leaders about topics/concepts with which the students are struggling. Another benefit of using PLTL, however, may be more subtle. The team leaders play an important mediating role between the instructor and the students, which can provide the instructor with a better insight into their students' attitudes and motivation toward the course (Gafney\& Varma-Nelson, 2007). Students are more likely to share problems they have with the course with one of their peers than with the instructor who assigns grades at the end of the course. 


\section{Conclusion}

The three inquiry-based, group-work approaches to instruction (SI, POGIL and PLTL) described in this paper were developed to promote student learning by creating social support and an active learning environment. They have all been shown to reduce the rates at which students drop out of introductory STEM courses and provide better learning experiences for students, peer leaders, and instructors. They are usually implemented by faculty who are dissatisfied with existing instructor-centered approaches associated with traditional lectures. POGIL and PLTL are often preferred more than SI because the instructor does not lose control over either what happens in the instructional sessions or the individuals delivering instruction.

In general, SI is the least expensive and most effortless of the three techniques. All three can be used with existing textbooks, although a chemistry textbook was developed that was designed to be used with both the philosophy of POGIL and the activities that were initially developed for implementation of this approach (Spencer, Bodner \& Rickard, 2011). The use of PLTL requires the construction of appropriate activities, or the adaptation of activities developed by others. It also involves the selection and training of peer team leaders. POGIL requires a significant change in the way the instructor envisions the use of class time and, once, again, the construction or adaptation of appropriate classroom activities. Anyone of these approaches to instruction would represent progress toward what has been called evidence-based practice by both its proponents (Slavin, 2002; Reynolds, 2008) and those who question its use (Biesta, 2007).

Both POGIL and PLTL evolved from projects designed to improve the teaching of introductory chemistry courses. Both soon expanded the range of courses in which they were used by moving into second-year and later courses in chemistry (see, for example, Tien, Roth \& Kampmeier, 2002; Hein, 2012; Hunnicutt, Grushow \& Whitnell, 2014). As noted by one of the individuals associated with both the development and dissemination of PLTL, this approach to teaching courses at his institution spread from one discipline to another as students who had experienced it in chemistry demanded that other disciplines implement it as well (Kampmeier. Personal communication).

At first, evidence to support the improvement in student performance associated with both POGIL and PLTL came from the chemical education research literature (Lewis \& Lewis, 2005; Wamser, 2006; Gafney \& Varma-Nelson, 2007; Straumanis \& Simons, 2008; Hein, 2012; Mitchell, Ippolito, \& Lewis, 2012; Shields, et al., 2012; Chan \& Bauer, 2015; Wilson, 2015; Frey, et al., 2018). Evidence of a positive effect on student performance was eventually reported for a wide variety of fields, including biology, computer science, engineering, mathematics, physics, and technology (Lyle \& Robinson, 2003; Tenney\& Houck, 2003; 2004; Micari, Streitwieser \& Light, 2006; Peterfreund, et al., 2008; Parkinson, 2009; Streitwieser \& Light, 2010; Darnell, et al. 2013; Drane, Micari \& Light, 2014; Hu, et al., 2014; Reyes Hernández et al. 2015; Snyder, Carter \& Wiles, 2015; Snyder, et al., 2016; Muller, Shacham \& Herscovitz, 2017; Sloane, Snyder \& Wiles, 2017; Liou-Mark, et al., 2018; Eren-Sisman, Cigdemoglu \& Geban, 2018).

In a study of peer-led team learning across a wide range of courses in a college of engineering, the authors concluded that students at all levels of performance benefitted from participation in these sessions, while "contributing more to students with higher academic capabilities" (Muller, Shacham\&Herscovitz, 2017). This result is interesting because studies of supplemental instruction have often found either no difference in the effect of SI on students with differing abilities or a larger effect for students from underrepresented minorities (Rath, et al., 2007). Furthermore, a five-year, multi-discipline study of students in STEM courses that disaggregated the effect of PLTL on students differentiated on the basis of "demographics (sex and race), academic preparation (math skills, chemistry content knowledge, 
and experience with college-preparatory coursework), ..." found that "... the positive effect of PLTL was comparable across demographic identity groups" (Frey et al., 2018) .

A recent study reported the use of a peer-lead approach for first-year chemical engineering graduate students on topics such as "professionalism, analyzing research articles, scientific writing mechanics, and designing presentation slides, among others" (Tocco, et al., 2018). The goal was to facilitate the grad students' adaptation to the process of "doing research." The study also noted, however, that senior graduate students who led these sessions also benefitted, as might be expected from studies of PLTL in undergraduate classrooms.

Considering the positive effect of PLTL at so many institutions, it is not surprising that studies have been done to examine the effectiveness of online cyber-PLTL. In both general chemistry (Smith, et al., 2014) and organic chemistry (Wilson, 2015; Wilson \& Varma-Nelson, 2018), students enrolled in the on-campus PLTL course earn more successful grades than their cPLTL counterparts.

\section{Acknowledgements}

The second author of this paper was a visiting scholar at Purdue University, and he was supported by 2219 program of Scientific and Technological Research Council of Turkey (TUBITAK).

\section{References}

Abraham, M. R., \& Renner, J. W. (1986). The sequence of learning cycle activities in high school chemistry. Journal of Research in Science Teaching, 23(2), 121-143.

American Association for the Advancement of Science. (1994). Benchmarks for science literacy. Oxford University Press.

Apugliese, A., \& Lewis, S. E. (2017). Impact of instructional decisions on the effectiveness of cooperative learning in chemistry through meta-analysis. Chemistry Education Research and Practice, 18(1), 271-278.

Arendale, D. R. (1994). Understanding the supplemental instruction model. New Directions for Teaching and Learning, 1994(60), 11-21.

Bhattacharyya, G., \& Bodner, G. M. (2014). Culturing reality: how organic chemistry graduate students develop into practitioners. Journal of Research in Science Teaching, 51(6), 694-713.

Biesta, G. (2007). Why “what works" won't work: Evidence based practice and the democratic deficit in educational research. Educational Theory, 57(1), 1-22.

Blanc, R. A., DeBuhr, L. E., \& Martin, D. C. (1983). Breaking the attrition cycle: The effects of supplemental instruction on undergraduate performance and attrition. The Journal of Higher Education, 54(1), 80-90.

Bodner, G. M. (1986). Constructivism: A theory of knowledge, Journal of Chemical Education, 63, 873-878.

Bodner, G.M. \& Metz, P. A. (2014). Twenty-five Years of Experience with Cooperative Learning in Chemistry, in Part 1, Teaching and Learning Chemistry, in Devetak, I., Gkažar, S. A., Eds., Learning with Understanding in the Chemistry Classroom, Springer, Berlin, pp. 129-148.

Bodner, G. M. (2015). Understanding the change toward a greener chemistry by those who do chemistry and those who teach chemistry, in Relevant Chemistry Education - From Theory to Practice, Eilks, I. and Hofstein, A., Eds., Rotterdam: Sense Publishers, pp. 263-284.

Bowman-Perrott, L., Davis, H., Vannest, K., Williams, L., Greenwood, C., \& Parker, R. (2013). Academic benefits of peer tutoring: A meta-analytic review of single-case research. School Psychology Review, 42(1), 39.

Brickhouse, N. W., Bodner, G. M. (1992). The Beginning Science Teacher: Narratives of Convictions and Constraints, Journal of Research in Science Teaching, 29, 471-485.

Bruffee, K. A. (1984). Collaborative learning and the" conversation of mankind." College English, 46(7), 635-652.

Burmeister, S. L. (1996). Supplemental Instruction: An interview with Deanna Martin. Journal of Developmental Education, $20(1), 22-26$.

Chan, J. Y., \& Bauer, C. F. (2015). Effect of peer led team learning (PLTL) on student achievement, attitude, and self concept in college general chemistry in randomized and quasi experimental designs. Journal of Research in Science Teaching, 52(3), 319346.

Congos, D. H., \&Schoeps, N. (1993). Does supplemental instruction really work and what is it anyway?. Studies in Higher Education, 18(2), 165-176.

Conway, C. J. (2014). Effects of guided inquiry versus lecture instruction on final grade distribution in a one-semester organic and biochemistry course. Journal of Chemical Education, 91(4), 480-483. 
Cracolice, M. S., \& Deming, J. C. (2001). A new teaching model focuses on student achievement through active learning Peer-led team learning. The Science Teacher, 68(1), 20.

Darnell, A., Becvar, J., Flores, B., Knaust, H., Lopez, J. \&Tinajero, J. (2013). Achieving student success using Peer-Led Team Learning (PLTL). Conference Proceedings of the Peer-Led Team Learning International Society, May 17-19, 2012, New York City College of Technology of the City University of New York, www.pltlis.org; ISSN 2329-2113.

Dawson, P., van der Meer, J., Skalicky, J., \& Cowley, K. (2014). On the effectiveness of supplemental instruction: A systematic review of supplemental instruction and peer-assisted study sessions literature between 2001 and 2010. Review of Educational Research, 84(4), 609-639.

Ding, N., \&Harskamp, E. G. (2011). Collaboration and peer tutoring in chemistry laboratory education. International Journal of Science Education, 33(6), 839-863.

Drane, D., Micari, M., \& Light, G. (2014). Students as teachers: effectiveness of a peer-led STEM learning programme over 10 years. Educational Research and Evaluation, 20(3), 210-230.

Eberlein, T., Kampmeier, J., Minderhout, V., Moog, R. S., Platt, T., Varma Nelson, P., \& White, H. B. (2008). Pedagogies of engagement in Science. Biochemistry and Molecular Biology Education, 36(4), 262-273.

Elmas, R., \&Geban, Ö. (2016). The Effect of Context-Based Chemistry Instruction on 9th Grade Students' Understanding of Cleaning Agents Topic and Their Attitude toward Environment. Education and Science, 41(185), 33-50.

Eren-Sisman, E. N., Cigdemoglu, C., \&Geban, Ö. (2018). The effect of peer-led team learning on undergraduate engineering students' conceptual understanding, state anxiety, and social anxiety. Chemistry Education Research and Practice, 19(3), 694210.

Fawcett, L. M., \& Garton, A. F. (2005). The effect of peer collaboration on children's problem solving ability. British Journal of Educational Psychology, 75(2), 157-169.

Frey, R. F., Fink, A., Cahill, M. J., McDaniel, M. A., \& Solomon, E. D. (2018). Peer-Led Team Learning in General Chemistry I: Interactions with Identity, Academic Preparation, and a Course-Based Intervention. Journal of Chemical Education, 95(12), 2103-2113.

Gafney, L., \& Varma-Nelson, P. (2007). Evaluating peer-led team learning: A study of long-term effects on former workshop peer leaders. Journal of Chemical Education, 84(3), 535.

Gerena, L. \&Keiler, L. (2012) Effective Intervention with Urban Secondary English Language Learners: How Peer Instructors Support Learning, Bilingual Research Journal, 35(1), 76-97.

Gilbert, B. D. (2015). Engaging Non-Majors in Chemistry through Brewing and POGIL. In Ethanol and Education: Alcohol as a Theme for Teaching Chemistry, Washington, D.C.: American Chemical Society, pp. 69-81.

Gosser, D., Roth, V., Gafney, L., Kampmeier, J., Strozak, V., Varma-Nelson, P., Radel, S. and Weiner, M.(1996). Workshop chemistry: Overcoming the barriers to student success. The Chemical Educator, 1(1), pp.1-17.

Gosser, D. K., \& Roth, V. (1998). The workshop chemistry project: Peer-led team-learning. Journal of Chemical Education, 75(2), 185.

Gosser, D. K., Cracolice, M.S., Kampmeier, J.A., Roth, V., Strozak, V.S., \& Varma-Nelson, P. (Eds.). (2001). Peer-led team learning: A guidebook. Upper Saddle River, NJ: Prentice-Hall.

Gosser, D. K., Strozak, V.S., Cracolice, M.S. (2006). Peer-Led team learning general chemistry (2nd Ed.). Upper Saddle River, NJ: Pearson Prentice Hall.

Groccia, J. E., \& Miller, J. E. (1996). Collegiality in the classroom: The use of peer learning assistants in cooperative learning in introductory biology. Innovative Higher Education, 21(2), 87-100.

Hanson, D. M. (2006). Instructor's guide to process-oriented guided-inquiry learning. Lisle, IL: Pacific Crest.

Hein, S. M. (2012). Positive impacts using POGIL in organic chemistry. Journal of Chemical Education, 89(7), 860-864.

Hmelo-Silver, C. E., Duncan, R. G., \& Chinn, C. A. (2007). Scaffolding and achievement in problem-based and inquiry learning: A response to Kirschner, Sweller, and Clark (2006). Educational Psychologist, 42(2), 99-107.

Hockings, S. C., DeAngelis, K. J., \& Frey, R. F. (2008). Peer-led team learning in general chemistry: implementation and evaluation. Journal of Chemical Education, 85(7), 990.

Hu, H. H., Lang, M., Kussmaul, C., Mayfield, C., \&Pirmann, T. (2014, March). Guided inquiry learning in context: perspectives on POGIL in CS. In SIGCSE (pp. 467-468).

Hunnicutt, S. S., Grushow, A., \&Whitnell, R. (2014). Guided-inquiry experiments for physical chemistry: The POGIL-PCL model. Journal of Chemical Education, 92(2), 262-268.

Kampmeier, J. A., Varma-Nelson, P., Wamser, C. C., Wedegaertner, D. K. (2006). Peer-led team learning organic chemistry (2nd Ed.). Upper Saddle River, NJ: Pearson Prentice Hall

King, A., Staffieri, A., \&Adelgais, A. (1998). Mutual peer tutoring: Effects of structuring tutorial interaction to scaffold peer learning. Journal of Educational Psychology, 90(1), 134.

Kirschner, P. A., Sweller, J., \& Clark, R. E. (2006). Why minimal guidance during instruction does not work: An analysis of the failure of constructivist, discovery, problem-based, experiential, and inquiry-based teaching. Educational Psychologist, 41(2), 75-86.

Lazonder, A. W., \&Harmsen, R. (2016). Meta-analysis of inquiry-based learning: Effects of guidance. Review of Educational Research, $86(3), 681-718$.

Lewis, S. E., \& Lewis, J. E. (2005). Departing from lectures: An evaluation of a peer-led guided inquiry alternative. Journal of Chemical Education, 82(1), 135. 
Lewis, S. E., \& Lewis, J. E. (2008). Seeking effectiveness and equity in a large college chemistry course: An HLM investigation of peer led guided inquiry. Journal of Research in Science Teaching, 45(7), 794-811.

Light, R. J. (1992). Explorations with students and faculty about teaching, learning, and student life. Memo to the Faculty Number 28, the University of Colorado at Boulder. Retrieved 4/18/2017 from http://www.colorado.edu/ftep/sites/default/files/attached-files/ftep_memo_to_faculty_28.pdf

Liou-Mark, J., Ghosh-Dastidar, U., Samaroo, D., \&Villatoro, M. (2018). The peer-led team learning leadership program for first year minority science, technology, engineering, and mathematics students. Journal of Peer Learning, 11(1), 65-75.

Lyle, K. S., \& Robinson, W. R. (2003). A statistical evaluation: Peer-led team learning in an organic chemistry course. Journal of Chemical Education, 80(2), 132-134.

Malm, J., Bryngfors, L., \&Mörner, L. L. (2012). Supplemental instruction for improving first-year results in engineering studies. Studies in Higher Education, 37(6), 655-666.

Micari, M., \& Light, G. (2009). Reliance to Independence: Approaches to learning in peer led undergraduate science, technology, engineering, and mathematics workshops. International Journal of Science Education, 31(13), 1713-1741.

Micari, M., Pazos, P., Streitwieser, B., \& Light, G. (2010). Small-group learning in undergraduate STEM disciplines: Effect of group type on student achievement. Educational Research and Evaluation, 16(3), 269-286.

Micari, M., Streitwieser, B., \& Light, G. (2006). Undergraduates leading undergraduates: Peer facilitation in a science workshop program. Innovative Higher Education, 30(4), 269-288.

Miller, V., Oldfield, E., \& Bulmer, M. (2012). Peer Assisted Study Sessions (PASS) in first-year chemistry and statistics courses: insights and evaluations. In Proceedings of the Australian conference on science and mathematics education (formerly UniServe Science Conference), Vol. 10.

Minderhout, V. \&Loertsher, J. (2008). Facilitation: The role of the instructor. In R. S. Moog and J. N. Spencer (ed.), Process Oriented Guided Inquiry Learning (POGIL), Washington, DC: American Chemical Society.

Mitchell, Y. D., Ippolito, J., \& Lewis, S. E. (2012). Evaluating peer-led team learning across the two semester general chemistry sequence. Chemistry Education Research and Practice, 13, 378-383.

Moog, R. S. \& Spencer, J. N. (2008). POGIL: An overview. In R. S. Moog and J. N. Spencer (ed.), Process Oriented Guided Inquiry Learning (POGIL), Washington, DC: American Chemical Society.

Moog, R.S., Creegan, F.J., Hanson, D.M., Spencer, J.N., Straumanis, A.R., Bunce, D.M. \&Wolfskill, T. (2009). POGIL: ProcessOriented Guided Inquiry Learning. In Chemists' Guide to Effective Teaching Volume II, Pienta, N.J., Cooper, M.M. \&Greenbowe, T.J., Eds.; Upper Saddle River, NJ: Pearson Prentice Hall.

Muller, O., Shacham, M., \&Herscovitz, O. (2017). Peer-led team learning in a college of engineering: First-year students' achievements and peer leaders' gains. Innovations in Education and Teaching International, 55(6), 660-671.

Parkinson, M. (2009). The effect of peer-assisted learning support (PALS) on performance in mathematics and chemistry. Innovations in Education and Teaching International,46(4), 381-392.

Pazos, P., Micari, M., \& Light, G. (2010). Developing an instrument to characterize peer led groups in collaborative learning environments: assessing problem solving approach and group interaction. Assessment E Evaluation in Higher Education, 35(2), 191-208.

Peterfreund, A. R., Rath, K. A., Xenos, S. P., \&Bayliss, F. (2008). The impact of supplemental instruction on students in STEM courses: Results from San Francisco State University. Journal of College Student Retention: Research, Theory E Practice, 9(4), 487503.

PLTL website. https://sites.google.com/view/pltl

POGIL website: https://www.pogil.org/

Quitadamo, I. J., Brahler, C. J., \& Crouch, G. J. (2009). Peer-led team learning: A prospective method for increasing critical thinking in undergraduate science courses. Science Educator, 18(1), 29.

Rath, K. A., Peterfreund, A. R., Xenos, S. P., Bayliss, F., \& Carnal, N. (2007). Supplemental instruction in introductory biology I: Enhancing the performance and retention of underrepresented minority students. CBE - Life Sciences Education, 6(3), 203-216.

Reynolds, S. (2008). Evidence-based practice: A critical appraisal. New York: John Wiley \& Sons.

Reyes Hernández, C.G., Carmona Pulido, J.M., De la Garza Chapa, R.I., Serna Vázquez, R.P., Alcalá Briones, R.D., Plasencia Banda, P.M., Villarreal Silva, E.E., Jacobo Baca, G., de la Garza Castro, O., Elizondo Omaña, R.E. and Guzmán López, S. (2015). Near peer teaching strategy in a large human anatomy course: Perceptions of near peer instructors. Anatomical Sciences Education, 8(2), 189-193.

Roth, V., Goldstein, E., \& Marcus, G. (2001). Peer-led team learning: A handbook for team leaders (Vol. 9). Upper Saddle River, NJ: Prentice Hall.

Ruder, S. M. Hunnicutt, S. S. (2008) POGIL in chemistry courses at a large urban university: A case study, in R. S. Moog, J. N. Spencer, Eds., Process Oriented Guided Inquiry Learning, American Chemical Society, Washington, DC.

Schön, D. A. (1983). The reflective practitioner: How professionals think in action. New York: Basic Books, 1983.

Shields, S. P., Hogrebe, M. C., Spees, W. M., Handlin, L. B., Noelken, G. P., Riley, J. M., \& Frey, R. F. (2012). A transition program for underprepared students in general chemistry: Diagnosis, implementation, and evaluation. Journal of Chemical Education, 89(8), 995-1000.

Shulman, L. S. (1986). Those who understand: Knowledge growth in teaching. Educational Researcher, 15(2), 4-31. 
Slavin, R. E. (2002). Evidence-based education policies: Transforming educational practice and research. Educational Researcher, 31(7), $15-21$.

Sloane, J., Snyder, J. J., \& Wiles, J. R. (2017). Peer-Led Team Learning improves minority student retention in STEM majors. bioRxiv, 200071.

Smith, J., Wilson, S. B., Banks, J., Zhu, L., \& Varma Nelson, P. (2014). Replicating Peer Led Team Learning in cyberspace: Research, opportunities, and challenges. Journal of Research in Science Teaching, 51(6), 714-740.

Snyder, J. J., Carter, B. E., \& Wiles, J. R. (2015). Implementation of the peer-led team-learning instructional model as a stopgap measure improves student achievement for students opting out of laboratory. CBE - Life Sciences Education, 14, 1-6.

Snyder, J. J., Sloane, J. D., Dunk, R. D., \& Wiles, J. R. (2016). Peer-led team learning helps minority students succeed. PLoS biology, 14(3), e1002398.

Spencer, J. N., Bodner, G. M., \& Rickard, L. H. (2011). Chemistry: Structure and dynamics, $5^{\text {th }}$ Ed., New York: John Wiley and Sons.

Steffe, L. P., \& Gale, J. E. (Eds.). (1995). Constructivism in education, Hillsdale, NJ: Lawrence Erlbaum, p. 159.

Stewart, B. N., Amar, F. G., \& Bruce, M. R. (2007). Challenges and rewards of offering peer-led team learning (PLTL) in a large general chemistry course. Australian Journal of Education in Chemistry, 67, 31-36.

Straumanis, A., \& Simons, E. A. (2008). A multi-institutional assessment of the use of POGIL in Organic Chemistry. In R. S. Moog and J. N. Spencer (ed.), Process Oriented Guided Inquiry Learning (POGIL), Washington, DC: American Chemical Society.

Streitwieser, B., \& Light, G. (2010). When Undergraduates Teach Undergraduates: Conceptions of and Approaches to Teaching in a Peer Led Team Learning Intervention in the STEM Disciplines--Results of a Two Year Study. International Journal of Teaching and Learning in Higher Education, 22(3), 346-356.

Teasley, S. D. (1995). The role of talk in children's peer collaborations. Developmental Psychology, 31(2), 207.

Tenney, A., \& Houck, B. (2003). Peer-led team learning in introductory biology and chemistry courses: A parallel approach. The Journal of Mathematics and Science: Collaborative Explorations, 6, 11-20.

Tenney, A., \& Houck, B. (2004). Learning about leadership. Journal of College Science Teaching, 33(6), 25.

Tien, L. T., Roth, V., \&Kampmeier, J. A. (2002). Implementation of a peer led team learning instructional approach in an undergraduate organic chemistry course. Journal of Research in Science Teaching, 39(7), 606-632.

Tocco, V. J., Buettner, K. E., Sciullo, M., Curtis, J. S., Butler, J. E. (2018) Work in Progress: Peer Led Research Methods Workshop for First Year Ph.D. Students. 2018 ASEE Southeastern Section March 4-6, 2018 at Embry-Riddle Aeronautical University Daytona Beach, Florida.

Treisman, U. (1992). Studying students studying calculus: A look at the lives of minority mathematics students in college. The College Mathematics Journal, 23(5), 362-372.

Trout, L. (2012). POGIL activities for high-school chemistry. Batavia, IL: Flinn Scientific

Tudge, J. (1992). Vygotsky, the zone of proximal development, and peer collaboration: Implications for classroom practice. In L. C. Moll (Ed.), Vygotsky and education: Instructional implications and applications of sociohistorical psychology (pp. 155-172). New York: Cambridge University Press.

Vygotsky, L. S. (1980). Mind in society: The development of higher psychological processes. Cambridge, MA: Harvard University press. Vygotsky, L. S. (2012). Thought and language. Cambridge, MA: MIT press.

Wagner, L. (1982). Peer teaching: Historical perspectives. Westport, CT: Greenwood Press.

Wamser, C. C. (2006). Peer-led team learning in organic chemistry: Effects on student performance, success, and persistence in the course. Journal of Chemical Education, 83(10), 1562.

Webb, N. M., \&Farivar, S. (1999). Developing productive group interaction in middle-school mathematics. In A. M. O'Donnell \& A. King (Eds.), Cognitive perspectives on peer learning, Mahwah, NJ: Erlbaum, (pp. 117-150).

Wilson, S. B. (2015). A comparison of first-semester organic chemistry students' experiences and mastery of curved-arrow formalism in face-to-face and cyber peer-led team learning, unpublished doctoral dissertation, Purdue University, West Lafayette, IN, USA.

Wilson, S. B., \& Varma-Nelson, P. (2016). Small Groups, Significant Impact: A Review of Peer-Led Team Learning Research with Implications for STEM Education Researchers and Faculty. Journal of Chemical Education, 93(10), 1686-1702.

Wilson, S. B., \& Varma-Nelson, P. (2018). Characterization of First-Semester Organic Chemistry Peer-Led Team Learning and Cyber Peer-Led Team Learning Students' Use and Explanation of Electron-Pushing Formalism. Journal of Chemical Education, 96(1), 25-34.

Woodward, A. E., Weiner, M., \&Gosser, D. (1993). Problem-solving workshops in general chemistry. Journal of Chemical Education, $70(8), 651$.

Yezierski, E. J, Bauer, C. F., Hunnicutt, S.S., Hanson, D. M., Amaral, K. E., \& Schneider, J. P. (2008). POGIL implementation in large classes, in R. S. Moog,J. N. Spencer, Eds., Process Oriented Guided Inquiry Learning, Washington, D.C.: American Chemical Society. 